\title{
The Role of CYP2C9 Gene Polymorphisms on Anticoagulant Therapy after Heart Valve Replacement
}

\author{
Hatice Yıldırım ${ }^{a}$ Lülüfer Tamer ${ }^{a}$ Nehir Sucub Uğur Atik $^{a}$ \\ a Department of Biochemistry and ${ }^{b}$ Department of Cardiovascular Surgery, Mersin University Faculty of Medicine, \\ Mersin, Turkey
}

\section{Key Words}

Heart valve replacement - Warfarin - CYP2C9 gene

polymorphism

\begin{abstract}
Objective: The aim of the present study was to investigate the role of CYP2C9 gene polymorphisms after heart valve replacement in a group of patients on warfarin therapy. $\mathbf{M a -}$ terials and Methods: The study population consisted of 74 patients with heart valve replacement. Peripheral blood was collected into evacuated tubes containing EDTA, and DNA was extracted from circulating leukocytes by using a high pure PCR template preparation kit. CYP2C9*2, CYP2C9*3 alleles were detected by using real-time PCR. Results: The patients with $\mathrm{CYP} 2 \mathrm{C} 9 * 1 / * 3$ and $\mathrm{CYP} 2 \mathrm{C9}{ }^{*} 2 /{ }^{*} 3$ genotypes were taking 28.21 and $24.47 \mathrm{mg}$, respectively, as mean weekly warfarin dose, whereas patients with CYP 2 C ${ }^{*} 1 /{ }^{*} 1$ genotype were taking $33.90 \mathrm{mg}$. Conclusion: The data show that patients with CYP2C9*1/*3 and CYP2C9*2/*3 genotypes needed a lower maintenance dose of warfarin than patients with CYP2C9*1/*1 wild-type genotype.
\end{abstract}

Copyright @ 2008 S. Karger AG, Basel
(C) 2008 S. Karger AG, Basel

1011-7571/08/0176-0464\$24.50/0

Accessible online at:

www.karger.com/mpp

\section{Introduction}

The commonest therapeutic procedure for the treatment of valvular pathology is the surgical replacement of defective heart valves [1]. Heart valve substitutes are of two principal types: mechanical prosthetic valves and bioprosthetic valves [1]. Despite their satisfactory hemodynamic results and durability, mechanical valves have a substantial risk of systemic thromboemboli and of thrombotic occlusion. Chronic anticoagulation therapy is required in all mechanical valve recipients, which may potentiate hemorrhagic complications $[1,2]$. Warfarin is a commonly used oral anticoagulant agent for the prevention of thromboembolic events in patients with mechanical heart valve replacement [3].

Efficacy of warfarin therapy is routinely monitored by the international normalized ratio (INR), which is a ratio of the time required for the patient's blood to coagulate relative to a standardized coagulation time [4-6]. Warfarin's anticoagulant effect is subject to wide interpatient variability, and despite careful dose titration based on evaluation of the INR, the risk of serious hemorrhage during warfarin therapy ranges from 1.3 to 4.2 per 100 patient years of exposure [7]. Although this complication can occur at therapeutic levels, identification of risk factors for the development of a high INR may identify pa- 
tients who are at high risk of bleeding. Warfarin therapy mediates its hematological effect predominantly through (S)-warfarin. After a variable half-life, (S)-warfarin is oxidized by cy tochrome P-450 2C9 (CYP2C9) to an inactive metabolite that is excreted in bile. Recent pharmacogenetic studies indicate that interindividual sensitivity to warfarin is partly based on the pharmacogenetics of CYP2C9 [8-10]. Two common variant alleles, CYP2C9*2, where cysteine substitutes for arginine at amino acid 144, and CYP2C9*3, where leucine substitutes for isoleucine at residue 359, have been identified. Each of these polymorphisms can occur in a heterozygous or homozygous form, and the presence of both polymorphisms results in a compound heterozygote (CYP2C9*2/*3) [8-10]. The CYP2C9*3 variant is less than $5 \%$ as efficient as wildtype enzyme, while CYP2C $9 * 2$ shows about $12 \%$ of wildtype activity [7-11]. Both of these variants are associated with decreased enzyme activity and hence impaired warfarin clearance $[10,11]$. This condition increases the anticoagulation effect of warfarin, thereby leading to a risk of bleeding complications. The determination of CYP2C9 gene polymorphisms in patients with heart valve replacement might be able to help in optimizing warfarin efficacy and minimizing bleeding.

The purpose of the present study was to investigate the effect of CYP2C9 gene polymorphisms on warfarin therapy in a group of patients after heart valve replacement.

\section{Subjects and Methods}

The protocol of this study was approved by the Ethics Committee of the School of Medicine, Mersin University, Mersin, Turkey. The patients were from the same geographic region (southern part of Turkey). The study population consisted of 74 patients (46 women and 28 men) from Mersin University Hospital, Turkey, with heart valve replacement who were receiving maintenance warfarin therapy with stable, therapeutic INR values between 2.5 and 3.5 for at least 3 months. Median age was 50.5 years (range 19-75), mean body mass index calculated as $\mathrm{kg} / \mathrm{m}^{2}$ was 24.3 (range 15.9-34.6). The number of patients with aortic valve replacement was 25 , mitral valve replacement 40 and combined aortic valve and mitral valve replacement 9. The warfarin dose was 15-52.5 mg per week. Patients younger than 18 years or those who had liver disease, malabsorption, or long-term diarrheal conditions or were taking medications known to significantly interact with warfarin therapy were excluded from the study.

DNA Extraction and Genotyping of CYP2C9

Peripheral blood for genetic analysis was collected into evacuated tubes containing EDTA. DNA was extracted from circulating leukocytes by using a high pure PCR template preparation kit (Roche Diagnostics, GmbH, Mannheim, Germany, catalog No. 1796 828). CYPC9*2 and CYP2C9*3 alleles were detected by using CYP2C9 mutation detection kits on real-time PCR with LightCycler instrument (Roche Diagnostics, catalog No. 3113914).

Hybridization probes 3 and 4 (anchor probes specific for nucleotide positions 430 and 1075, respectively), CYP2C9 enzyme solution (Taq polymerase), CYP2C9 reaction mixture (DNA polymerase reaction buffer, dNTP mix), CYP2C9 control template (heterozygous plasmid DNA), sterile $\mathrm{H}_{2} \mathrm{O}$ (PCR grade) were used. For PCR, $10.7 \mu \mathrm{l} \mathrm{H}_{2} \mathrm{O}, 2 \mu \mathrm{l}$ mutation detection mix, $2 \mu \mathrm{l} \mathrm{CYP} 2 \mathrm{C} 9$ reaction mix, $0.3 \mu$ l enzyme solution and $50 \mathrm{ng}$ of genomic DNA were taken in a final volume of $20 \mu \mathrm{l}$. The cycling programs for CYP2C 9 are 1 cycle of denaturation $\left(95^{\circ} \mathrm{C}, 600 \mathrm{~s}\right.$, ramp rate $20^{\circ} \mathrm{C} /$ s) and 45 cycles of amplification including denaturation $\left(95^{\circ} \mathrm{C}\right.$, $10 \mathrm{~s}$, ramp rate $\left.20^{\circ} \mathrm{C} / \mathrm{s}\right)$, annealing $\left(55^{\circ} \mathrm{C}, 10 \mathrm{~s}\right.$, ramp rate $\left.20^{\circ} \mathrm{C} / \mathrm{s}\right)$ and extension $\left(72^{\circ} \mathrm{C}, 19 \mathrm{~s}\right.$, ramp rate $\left.3^{\circ} \mathrm{C} / \mathrm{s}\right)$. After amplification, a melting curve was generated by holding the reaction at $95^{\circ} \mathrm{C}$ for $60 \mathrm{~s}\left(\right.$ ramp rate $20^{\circ} \mathrm{C} / \mathrm{s}$ ) and cooling slowly (ramp rate $20^{\circ} \mathrm{C} / \mathrm{s}$ ) to $40^{\circ} \mathrm{C}$ and than heating to $80^{\circ} \mathrm{C}\left(\mathrm{ramp}\right.$ rate $\left.0.1^{\circ} \mathrm{C} / \mathrm{s}\right)$. The final step cooling was $1 \mathrm{cycle} 40^{\circ} \mathrm{C}, 30 \mathrm{~s}$ (ramp rate $20^{\circ} \mathrm{C} / \mathrm{s}$ ).

\section{Measurement of INR}

Venous blood was obtained by venipuncture and collected into tubes containing $3.8 \%$ sodium citrate $(9: 1 \mathrm{vol} / \mathrm{vol})$ and plasma separated. Plasma prothrombin times were measured with a Behringer Coagulation System (Dade Behring, Marburg, Germany) using Thromborel S (Dade Behring) as thromboplastin. The INRs were calculated according to the formula INR = (patient prothrombin time/geometric mean normal prothrombin time) $)^{\mathrm{ISI}}$. The geometric mean normal prothrombin time was calculated using 20 normal plasmas. The manufacturer's international sensitivity index (ISI) was used for INR calculation.

\section{Statistical Analyses}

Factorial covariance was used to define age, sex, and body mass index; basic variance analysis was used to detect the effect of CYP2C9*2 and CYP2C9*3 gene polymorphisms on warfarin dose and INR levels. In all analyses, $\mathrm{p}<0.05$ was considered significant. All statistical calculations were performed using the SPSS software package version 10.0 (Windows SPSS Inc., Chicago, Ill., USA).

\section{Results}

There was no association of age, sex and body mass index with CYP2C9 gene polymorphism, warfarin dose and INR $(\mathrm{p}=0.1)$. The allele frequencies were 0.69 for CYP2C9*1, 0.13 for CYP2C9*2 and 0.18 for CYP2C9*3. CYP2C9 genotypes is in Hardy-Weinberg equilibrium $(\mathrm{p}=0.88)$ and the distribution of CYP2C9 genotypes is given in table 1 . The mean warfarin doses and INR are listed in table 2 . Patients with CYP $2 \mathrm{C} 9 * 1 /{ }^{*} 3$ and CYP2C $9 * 2 * 3$ genotypes required a significantly lower maintenance dose of warfarin $(28.21 \pm 5.14$ and $24.47 \pm$ $5.17 \mathrm{mg}$, respectively) than patients with CYP2C ${ }^{*} 1 /{ }^{*} 1$ wild-type genotype $(33.90 \pm 7.25 \mathrm{mg} ; \mathrm{p}=0.028$ for 
Table 1. Distribution of CYP2C9 genotypes in patients

\begin{tabular}{lcr}
\hline Genotype & \multicolumn{2}{c}{ Frequency } \\
\cline { 2 - 3 } & $\mathrm{n}$ & \multicolumn{1}{c}{$\%$} \\
\hline $\mathrm{CYP} 2 \mathrm{C} 9 * 1 / *$ & 48 & 64.9 \\
$\mathrm{CYP} 2 \mathrm{C} 9 * 1 / * 3$ & 7 & 9.5 \\
$\mathrm{CYP} 2 \mathrm{C} 9 * 2 / * 3$ & 19 & 25.7 \\
$\mathrm{CYP} 2 \mathrm{C} 9 * 1 / * 2$ & 0 & 0.0 \\
CYP2C $9 * 2 / * 2$ & 0 & 0.0 \\
CYP2C $9 * 3 / * 3$ & 0 & 0.0
\end{tabular}

The distribution of the genotypes is in Hardy-Weinberg equilibrium $(\mathrm{p}=0.88)$. CYP $2 \mathrm{C} 9 * 1 /{ }^{*} 1=$ Wild-type; CYP $2 \mathrm{C} 9 * 1 /{ }^{*} 3=$ heterozygous ${ }^{*} 3$; CYP $2 \mathrm{C} 9 * 2 /{ }^{*} 3=$ heterozygous ${ }^{*} 2 /{ }^{*} 3$; CYP$2 \mathrm{C} 9^{*} 1 /{ }^{*} 2=$ heterozygous ${ }^{*} 2$; CYP $2 \mathrm{C} 9^{*} 2 /{ }^{*} 2=$ homozygous ${ }^{*} 2$; CYP2C9*3/*3 = homozygous *3.

Table 2. Mean ( \pm SD) weekly warfarin dose and INR levels for the CYP2C9 genotypes

\begin{tabular}{lrllll}
\hline $\begin{array}{l}\text { CYP2C9 } \\
\text { genotype }\end{array}$ & $\mathrm{n}$ & $\begin{array}{l}\text { Warfarin } \\
\text { dose, mg }\end{array}$ & $\begin{array}{l}\mathrm{p} \\
\text { value }\end{array}$ & $\begin{array}{l}\text { Mean } \\
\text { INR }\end{array}$ & $\begin{array}{l}\mathrm{p} \\
\text { value }\end{array}$ \\
\hline${\text { CYP2C9* } 1{ }^{*} 1}^{*}$ & 48 & $33.90 \pm 7.25$ & ref. & $2.32 \pm 0.57$ & ref. \\
CYP2C9* $1 / * 3^{*}$ & 7 & $28.21 \pm 5.14$ & 0.028 & $2.91 \pm 0.29$ & 0.001 \\
CYP2C9* $2 / * 3^{*}$ & 19 & $24.47 \pm 5.17$ & 0.000 & $2.84 \pm 0.80$ & 0.015 \\
\hline
\end{tabular}

$\mathrm{CYP} 2 \mathrm{C} 9 * 1 / * 3, \mathrm{p}=0.000$ for $\left.\mathrm{CYP} 2 \mathrm{C} 9 * 2 /{ }^{*} 3\right)$. Patients with CYP2C $9 * 1 / * 3$ and CYP2C $9 * 2 / * 3$ genotypes had mean INR values significantly higher than CYP2C $9 * 1 /{ }^{*} 1$ wildtype genotype $\left(\mathrm{p}=0.001\right.$ for $\mathrm{CYP} 2 \mathrm{C} 9^{*} 1{ }^{*} 3, \mathrm{p}=0.015$ for CYP2C9*2/*3).

\section{Discussion}

Warfarin therapy is problematic after heart valve replacement due to a narrow therapeutic index coupled with significant interpatient variability in warfarin sensitivity [12]. The CYP2C9 gene encodes the enzyme that catalyzes the conversion of warfarin to inactive metabolites $[12,13]$. Any alteration in its activity would, therefore, have an impact on warfarin pharmacokinetics and clinical efficacy. Two common variant alleles of CYP2C9 (CYP2C9*2 and CYP2C9*3) are seen in more than $30 \%$ of European and Caucasian populations, but over $95 \%$ of Asian and American populations carry the wild-type allele [14]. It is well established that CYP2C9 and VKORC1 polymorphisms make a significant contribution to the interindividual variability in warfarin dose requirement $[12,15]$. As a consequence, patients are at risk of developing extreme levels of anticoagulation after receiving standard dosing regimens, particularly during initiation of therapy [13].

In the present study, the frequencies of $\mathrm{CYP} 2 \mathrm{C} 9 * 1 /{ }^{*} 1$, $\mathrm{CYP} 2 \mathrm{C} 9^{*} 1{ }^{*} 3$ and $\mathrm{CYP} 2 \mathrm{C} 9 * 2 /{ }^{*} 3$ are $64.9,9.5$ and $25.7 \%$, respectively. Patients with CYP $2 \mathrm{C} 9 * 1 /{ }^{*} 3$ and CYP2C $9 * 2 / * 3$ alleles showed a decrease of 16.7 and $27.8 \%$ in warfarin dose required, compared with patients having the CYP2C $9 * 1 /{ }^{*} 1$ wild-type genotype. Whether these mutations affect functional activity through decreased enzyme expression or altered substrate binding or through other mechanisms remains to be determined [16]. Our findings support the previous suggestion that CYP2C9 gene polymorphisms in patients warrants adjustment of warfarin dose in order to optimize its efficacy and minimize bleeding.

\section{Conclusion}

This study shows that patients carrying CYP $2 \mathrm{C} 9 * 1 /{ }^{*} 3$ and $\mathrm{CYP} 2 \mathrm{C} 9{ }^{*} 2 /{ }^{*} 3$ need a lower warfarin dose than patients having CYP $2 \mathrm{C} 9 * 1 /{ }^{*} 1$ wild-type genotype. CYP $2 \mathrm{C} 9$ genotyping before anticoagulant therapy might help to guide warfarin dosage in patients with heart valve replacement, but prospective trials of such protocols are needed to show the real clinical value of genotyping in this situation.

\section{Acknowledgment}

This study was supported by the Research Foundation of Mersin University [Project Code No. BAP SBE BK (HY) 2004-1 YL]. The authors are grateful to Dr. Handan Çamdeviren for statistical evaluation.

$\begin{aligned} \text { References } & \begin{array}{l}\text { Vongpatanasin W, Hillis D, Lange RA: Pros- } \\ \text { thetic heart valves. N Engl J Med 1996;335: } \\ \\ 407-416 .\end{array} \\ 2 & \text { Schoen FJ, Levy RJ: Tissue heart valves: cur- } \\ & \text { rent challenges and future research perspec- } \\ & \text { tives. J Biomed Mater Res 1999;47:439-465. } \\ 3 & \text { Higashi MK, Veenstra DL, Kondo LM, } \\ & \text { Wittkowsky AK, Srinouanprachanh SL, } \\ & \text { Farin FM, Rettie AE: Association between } \\ & \text { CYP2C9 genetic variants and anticoagula- } \\ & \text { tion-related outcomes during warfarin ther- } \\ & \text { apy. JAMA 2002;287:1690-1698. }\end{aligned}$

Ylldırım/Tamer/Sucu/Atik 
4 Adcock DM, Koftan C, Crisan D, Kiechle FL: Effect of polymorphisms in the cytochrome P450 CY P2C9 gene on warfarin anticoagulation. Arch Pathol Lab Med 2004;128:13601363.

5 Hirsh J, Dalen JE, Anderson DR, Poller L, Bussey H, Ansell J, Deykin D: Oral anticoagulants: mechanism of action, clinical effectiveness, and optimal therapeutic range. Chest 2001;119(suppl 1):8-21.

-6 Penning-van Beest FJA, van Meegen E, Rosendaal FR: Characteristics of anticoagulant therapy and comorbidity related to overanticoagulation. Thromb Haemost 2001;86:569-574.

-7 Stroke Prevention in Atrial Fibrillation Investigators: Bleeding during antithrombotic therapy in patients with atrial fibrillation. Arch Intern Med 1996;156:409-416.
8 Taube J, Halsall D, Baglin T: Influence of cytochrome $\mathrm{P} 450 \mathrm{CYP} 2 \mathrm{C} 9$ polymorphisms on warfarin sensitivity and risk of over-anticoagulation in patients. Blood 2000;96:18161819.

9 Choonara IA, Cholerton S, Haynes BP, Breckenridge AM, Park BK: Stereoselective interaction between the R-enantiomer of warfarin and cimetidine. Br J Clin Pharmacol 1986;21:271-277.

10 Stubbins MJ, Harries LW, Smith G, Tarbit $\mathrm{MH}$, WolfCR: Genetic analysis of the human cytochrome P450 CYP2C9 locus. Pharmacogenetics 1996;6:429-439.

11 Rettie AE, Wienkers LC, Gonzalez FJ, Trager WF, Korzekwa KR: Impaired S-warfarin metabolism catalyzed by R144C allelic variant of CYP2C9. Pharmacogenetics 1994;4: $39-42$.

-12 Tabrizi AR, Zehnbauer BA, Borecki IB, McGrath SD, Buchman TG, Freeman BD: The frequency and effects of cytochrome P450 (CYP) 2C9 polymorphisms in patients receiving warfarin. J Am Coll Surg 2002;194: 267-273.
13 Harrison L, Johnston M, Massicotte MP, Crowther M, Moffat K, Hirsh J: Comparison of 5-mg and 10-mg loading doses in initiation of warfarin therapy. Ann Intern Med 1997;126:133-136.

14 Lee CR, Goldstein JA, Pieper JA: Cytochrome P4502C9 polymorphisms: a comprehensive review of the in-vitro and human data. Pharmacogenetics 2002;12:251-263.

15 D’Andrea G, D’Ambrosio RL, Di Perna P, Chetta M, Santacroce R, Brancaccio V: A polymorphism in the $\mathrm{VKORC1}$ gene is associated with an interindividual variability in the dose-anticoagulant effect of warfarin. Blood 2005; 105:645-649.

16 Steward DJ, Haining RL, Henne KR, Davis G, Rushmore TH, Trager WF, Rettie AE: Genetic association between sensitivity to warfarin and expression of CYP2C9*3. Pharmacogenetics 1997;7:361-367. 